\title{
Emotional and cognitive influences on pain experience
}

Citation for published version (APA):

Peters, M. L. (2015). Emotional and cognitive influences on pain experience. Modern Trends in Pharmacopsychiatry, 30, 138-152. https://doi.org/10.1159/000435938

Document status and date:

Published: 01/01/2015

DOI:

10.1159/000435938

\section{Document license:}

Taverne

\section{Please check the document version of this publication:}

- A submitted manuscript is the version of the article upon submission and before peer-review. There can be important differences between the submitted version and the official published version of record.

People interested in the research are advised to contact the author for the final version of the publication, or visit the DOI to the publisher's website.

- The final author version and the galley proof are versions of the publication after peer review.

- The final published version features the final layout of the paper including the volume, issue and page numbers.

Link to publication

\footnotetext{
General rights rights.

- You may freely distribute the URL identifying the publication in the public portal. please follow below link for the End User Agreement:

www.umlib.nl/taverne-license

Take down policy

If you believe that this document breaches copyright please contact us at:

repository@maastrichtuniversity.nl

providing details and we will investigate your claim.
}

Copyright and moral rights for the publications made accessible in the public portal are retained by the authors and/or other copyright owners and it is a condition of accessing publications that users recognise and abide by the legal requirements associated with these

- Users may download and print one copy of any publication from the public portal for the purpose of private study or research.

- You may not further distribute the material or use it for any profit-making activity or commercial gain

If the publication is distributed under the terms of Article $25 \mathrm{fa}$ of the Dutch Copyright Act, indicated by the "Taverne" license above, 
Finn DP, Leonard BE (eds): Pain in Psychiatric Disorders. Mod Trends Pharmacopsychiatry.

Basel, Karger, 2015, vol 30, pp 138-152 (DOI: 10.1159/000435938)

\title{
Emotional and Cognitive Influences on Pain Experience
}

\author{
Madelon L. Peters
}

Department of Clinical Psychological Science, Maastricht University, Maastricht, The Netherlands

\begin{abstract}
Multiple emotional and cognitive factors impact on the experience of pain. This chapter will review some of the most important emotional and cognitive determinants of the pain experience as found in experimental and clinical studies with human participants. Emotional factors that may increase pain perception are anxiety, depression and anger. Positive emotions usually decrease perceived pain. The cognitive factors attention, expectancy and appraisal can either increase or decrease pain experiences depending on their specific focus and content. Many brain regions are involved in nociceptive processing and bringing pain into awareness. There are profound interconnections between areas processing sensory, emotional and cognitive information. Descending pathways from cortical areas to the midbrain and spinal levels can facilitate or inhibit spinal nociceptive information and thereby afferent nociceptive input to the brain. The underlying mechanisms of the various emotional and cognitive modulatory influences may partly overlap, but also have some unique aspects. What becomes clear is that pain is not merely a reflection of the nociceptive input, but should be considered as a complex experience shaped by psychological factors that may be unique for each individual.

(c) 2015 S. Karger AG, Basel
\end{abstract}

Pain is not solely determined by the degree of nociceptive input, but also depends on psychological factors such as emotional state and cognitive appraisal. The International Association for the Study of Pain (IASP) defines pain as 'an unpleasant sensory and emotional experience associated with actual or potential tissue damage, or described in terms of such damage'. According to this definition, pain is unquestionably a bodily sensation, but it is also always unpleasant and therefore an emotional experience [1]. Brain imaging research has demonstrated that sensory, affective and cognitive regions interact to determine the final pain experience. Several decades of research 
have identified some of the most important emotional and cognitive determinants. This chapter will discuss successively: fear and anxiety, depression, anger and positive affect as the emotional components of pain, and attention, expectancy and appraisal as the cognitive components. Even though for the sake of this overview these aspects are treated separately, as we will see later, some of these components are inherently linked to each other. It should also be kept in mind that although the focus of this chapter is on emotions and cognitions as determinants of the pain experience, there is a reciprocal relationship. Moreover, as implied in the definition, emotions are also an integral part of the pain experience itself.

\section{Emotional Factors}

Before proceeding to reviewing emotional modulation of pain, a clarification of terms is in order. Emotion is usually conceptualized as a reaction to a particular elicitor and has a clearly defined focus. Mood is a more diffuse state without a clear focus. The term affect is used to refer to emotions and mood collectively. It should also be noted that emotional factors can refer to short-lasting states (e.g. after anger induction) or to longer-lasting states (e.g. clinical depression). The overview presented below will incorporate studies that have focused on both short- and long-lasting emotional states and moods.

\section{Anxiety and Pain-Related Fear}

Research in healthy volunteers using experimental pain stimuli has demonstrated that anxiety, specifically pain-related anxiety, can increase pain sensitivity and exacerbate the pain experience [2-6]. Additionally, in clinical situations anticipatory anxiety has been associated with higher pain reports. For instance, anxiety concerning injections led to higher reported pain after dental injections [7]. Rhudy and Meager [8] distinguished between the effects of fear versus anxiety. Anxiety, defined as the anticipation of potential threats, was proposed to lead to augmentation of the pain experience. Fear, defined as the alarm reaction to a present threat, was proposed to suppress pain experiences and to mobilize the body to allow escape. Their experiment confirmed these predictions: when moderately intense shocks (supposed to elicit fear) were delivered prior to a painful test stimulus, pain was inhibited; however, when threat of intense shocks was induced without actually giving these shocks, sensitivity for the test stimulus was enhanced [8]. The anxiety state would be most characteristic of the emotions experienced in most experimental studies and in clinical situations. Fear and inhibition of pain, on the other hand, may typically be seen in extreme situations such as during combat or assault, where pain reactions might hamper escape and endanger survival. In much of the literature this distinction between anxiety and fear is, however, not made and the term 'pain-related fear' is used to denote both the reaction to current pain as well as anticipatory anxiety for upcoming pain. 
Pain modulation by anxiety can be traced back to brain interactions of emotional and sensory areas. Incoming nociceptive signals are processed in many different brain areas such as the somatosensory cortex, anterior cingulate cortex (ACC), insula, amygdala, thalamus and hypothalamus $[9,10]$. Projections from the insula and prefrontal cortex, via periaqueductal gray (PAG) to brainstem nuclei, and finally to the spinal cord are involved in descending modulation of pain. This descending modulation can be both inhibitory and excitatory, and involves among other endogenous opioids, noradrenaline and serotonin [9-11].

Anxiety can directly or indirectly influence many different areas involved in coding sensory and affective aspects of pain as well as areas involved in descending modulation. For instance, one study found that conditioned anxiety increased activation of the entorhinal cortex of the hippocampal formation, which subsequently affected activity in the midinsula intensity coding area [12]. Many studies also point to the pivotal role of prefrontal areas, the amygdala and the PAG in conveying the influence of anxiety on pain. Anxiety-prone individuals show impaired prefrontal functioning, which is generally assumed to inhibit pain [9]. In addition, anxious people show a different connectivity pattern between the anterior insular cortex and the PAG, suggestive of less efficient pain modulation $[13,14]$. This is not an exhaustive overview of imaging studies that have shown how anxiety might impact on the neural pain network, as a variety of mechanisms have in fact been identified [14].

Anxiety has also been implicated to play a role in chronification of pain. One of the most influential psychological models of chronic pain is the fear-avoidance model $[15,16]$. This model has mostly been applied to chronic musculoskeletal pain. According to this model, fear of pain and fear of reinjury may hamper recovery from an acute pain episode because this anticipatory anxiety motivates avoidance behavior and inactivity. Persistent inactivity may be maladaptive and can lead to a negative spiral of deteriorated physical condition, disability and distress, and subsequently to increased pain intensity. Correlational studies have indeed confirmed the predicted relationships between pain-related fear and pain intensity, disability and distress in patients with musculoskeletal pain $[17,18]$. More pertinent for its proposed etiological role, prospective studies have shown that pain-related fear in patients seeking care for acute pain may be predictive of pain persistence and long-term disability and sick leave [19-21]. Pain-related fear is also related to the future inception of (back) pain in the general population $[22,23]$.

A suitable model to study the transition from acute to chronic pain is the postsurgical pain model. Surgery causes tissue injury and massive nociceptive input. Depending on the specific procedure, patients experience acute postsurgical pain for a few hours to several days or even weeks after the operation, which for the majority of patients will subside in time. However, a minority of patients can go on to develop chronic postsurgical pain (CPSP). Prevalence estimates for CPSP have ranged from 5 to $30 \%$ for the most common surgical procedures, but can be as high as $50 \%$ for 
amputations and thoracotomy $[24,25]$. Because elective surgery is a planned procedure, it allows for the assessment of psychological variables before the intervention takes place. Studies on predictors of CPSP have identified general anxiety as well as surgery-specific anxiety as important predictors of long-term surgical outcome in terms of pain and disability [26, 27].

In conclusion, anxiety seems to aggravate the subjective experience of a nociceptive stimulus, it can trigger maladaptive behaviors in patients with chronic pain and it may predispose people to develop a chronic pain condition. As the next sections will demonstrate, anxiety is certainly not the only emotion affecting the pain experience. However, it is probably the most researched factor in the past decades with generally robust findings.

\section{Depression}

A vast number of studies are available demonstrating that negative emotions increase pain perception. Most studies examining the effect of negative emotion induction on experimental pain have not differentiated between the specific emotions that were elicited (e.g. disgust, anger, depression), with a few exceptions. Zelman et al. [28] used the Velten mood induction procedure, where participants read depressive statements, and found lowered tolerance for cold pressor pain in comparison to a neutral mood condition. Berna et al. [29] used the Velten procedure accompanied by sad music to induce a depressed mood and applied tonic heat stimuli in the scanner. Depressed mood induction led to higher perceived pain unpleasantness and increased activity in various pain-related brain areas including prefrontal and anterior cingulate cortices and the hippocampus.

Other studies have examined pain sensitivity and pain processing in patients with major depressive disorders. These studies show an inconsistent relation between clinical depression and pain sensitivity, with hypersensitivity, hyposensitivity or no differences between depressed and nondepressed participants [9]. Brain imaging studies also found contradictory results. For instance Bär et al. [30] found depressive patients have less sensitivity for thermal pain stimuli with concomitant increased activation of the ventrolateral and dorsolateral prefrontal cortices, which have a paininhibiting function. On the other hand, Strigo et al. [31] observed decreased activation in pain modulatory areas including prefrontal areas and the PAG during heat pain stimulation.

Clinical observation and epidemiological studies have demonstrated a strong association between chronic pain and depression. As much as $50 \%$ of patients with chronic pain suffer from a comorbid depressive disorder [32,33]. Concurrent depressive symptoms in patients with chronic pain are associated with increased disability and an augmented pain experience $[34,35]$. Imaging studies in patients with chronic pain have shown that concomitant depression is especially associated with increased activity in brain regions involved in affective processing both in response to experimental pain and disease-relevant pain $[36,37]$. 
A long-standing debate is whether chronic pain causes depression, or whether depression is a risk factor for developing chronic pain. Both may in fact be true, with one condition constituting a risk factor for the development of the other condition. In addition, the co-occurrence of chronic pain and depression may be due to shared underlying mechanisms, either cognitive behavioral (e.g. repetitive negative thinking, avoidance [38]) or biological (e.g. neuroinflammation [39], genetic [40]). Longitudinal studies provide evidence that having depression might increase the chance of a subsequent pain disorder, which is consistent with the risk factor or shared vulnerability view. The incidence of developing back pain in previously pain-free individuals was found to be 2-3 times higher in individuals who suffered from a previous or current depressive disorder $[41,42]$. Also with regard to the development of CPSP, preoperative depression has been identified as a risk factor, although less consistently so compared to anxiety $[43,44]$.

\section{Anger}

Less frequently researched than the above two negative emotions is the influence of anger on pain. Nevertheless, evidence is accumulating that anger can also influence pain perception. Several studies have examined the effects of anger induction on pain sensitivity in pain patients or healthy controls and generally found increased sensitivity for experimental pain stimulation $[45,46]$. In addition, anger management style may influence pain sensitivity. Especially individuals who are more prone to express anger in a physical or verbal way (i.e. anger-out style) show greater sensitivity, and this was found for experimental pain, as well as for acute postsurgical pain $[47,48]$. It has been speculated that deficient endogenous opioidergic modulation in the rostral limbic system might underlie both increased pain sensitivity and a reduced ability to adequately regulate anger [48]. However, anger management style and state anger can show a complex interaction; when people with a high level of anger cannot express their anger (e.g. in a lab situation it is usually not appropriate to express anger), this may indeed increase sensitivity; however, when anger is expressed, this may in fact normalize or even decrease pain sensitivity $[48,49]$.

Some indication for a possible causal relation between anger regulation and increased pain comes from daily diary studies with chronic low back pain patients [49, 50]. Behavioral anger expression and anger inhibition were associated with increased pain intensity, more pain interference and decreased functioning at subsequent assessment times. In addition to a direct effect on the pain experience, anger may also have a negative effect on treatment outcome and lead to interpersonal problems [51, 52].

\section{Positive Emotions}

Although most research has focused on the role of negative emotions, several studies have specifically examined the effect of positive emotions on pain. It should be noted that positive emotions are not just the opposite of negative emotions, they are 
correlated but can also vary partly independently [53]. Experimental studies in healthy volunteers have demonstrated that the induction of positive emotions leads to reduced pain sensitivity (for an overview, see Finan and Garland [54]). Again, both supraspinal modulation (i.e. interactions between pain and emotional networks within the brain [14]) and descending pain modulation are involved, as shown by a decrease in a spinal nociceptive reflex after positive emotion induction $[55,56]$.

Positive emotions may also have a protective role in the transition from acute to chronic pain because they may protect against the development and spreading of pain-related fear. In an elegant experiment, fear for a specific hand movement was experimentally induced by pairing this movement with electrical shock. During the extinction phase, where shocks were no longer given, participants with high trait positive affect showed faster fear reduction than participants with low positive affect [57]. A subsequent study showed that the induction of positive emotions could prevent spreading of fear to new movements and to lower pain expectancy for these movements [58].

In chronic pain patients, positive affect and pain intensity have repeatedly been found to be correlated [59]. However, many of these studies were cross-sectional and did not allow conclusions on the direction of causality. A few studies nevertheless suggested that positive affect may be prospectively related to less intense pain. For instance, a diary study indicated that an increase in positive emotions was related to lower pain reports at subsequent time points in patients with rheumatoid arthritis [60]. Other studies have indicated that positive emotions may buffer the effect of pain on physical functioning and distress. Positive emotions were related to faster functional recovery after hip fractures [61] and to less distress in patients with rheumatoid arthritis at times when pain intensity was high [62]. Induction of positive emotions may reduce clinical pain and distress. A randomized controlled trial studying the effects of an online positive psychology intervention on daily pain demonstrated that people reporting mild-to-moderate pain before the intervention showed significant reductions in pain at the 6-month follow-up [63]. Preliminary data from a study using virtual reality to induce positive emotions suggest that this intervention might decrease pain and distress, and increase activity level in fibromyalgia patients [64].

In sum, positive emotions may have pain-reducing qualities. This effect may at least be partly dependent on their incompatibility with pain-related fear and probably other negative emotions.

\section{Cognitive Factors}

In addition to emotional factors, cognitive factors also influence the perception and experience of pain. Cognition is defined as the mental processes related to gaining knowledge and encompasses such functions as attention, memory and reasoning. The cognitive processes most studied in relation to pain are attention, expectancy and appraisal. 


\section{Attention}

Attention and nociception are intrinsically related and have a bidirectional relationship with each other [65]. Pain can involuntarily capture attention, especially when it is intense, novel or threatening [66]. A shift in attention towards the source of a potential threat enables escape and prevention from further harm. On the other hand, directing attention towards pain and bringing it into focal awareness may increase its intensity. In reverse, directing attention away from pain will exclude it from further processing and lead to less pain [67].

Numerous studies have documented the effect of attention manipulations on perceived intensity of experimental pain, with the general finding that distraction by a competing task diminishes pain and focusing on pain increases it $[68,69]$. Brain imaging studies have shown that distraction away from pain is associated with decreased activity in ascending pain pathways, including the thalamus, somatosensory areas, insular cortex and ACC, and increased activity in descending pain modulatory pathways involving the ACC and PAG [70-72]. Animal studies have shown the involvement of dopamine, serotonin and endocannabinoids in attentional modulation of pain $[73,74]$. However, involvement of the descending system in attentional control has recently been questioned as some studies suggest that the underlying neural mechanisms of attentional modulation may be partly distinct from those underlying the effects of emotion on pain [72]. When emotion and attention where independently manipulated, emotional influences on pain perception did involve the PAG and ACC, suggestive of descending modulation, but attentional modulation affected the superior posterior parietal cortex and the anterior insula [75]. The latter is consistent with orienting attention toward sensory information and optimizing the cortical presentation of the attended stimulus [74]. Nevertheless, even though attentional and emotional modulations of pain may originate from different cerebral sources and may partly act through different mechanisms, there are also communalities between their actions, e.g. both can modulate activity in the anterior insula [76].

Attentional processes also influence the experience of clinical pain. Heightened attention towards painful signals - also referred to as hypervigilance - have been implied in the transition from acute to chronic pain [16]. Such hypervigilance may especially become apparent in individuals that are highly fearful of pain and for whom avoidance of pain is the main goal $[77,78]$. In patients with chronic pain, high pain vigilance was indeed found to be associated with higher pain intensity $[79,80]$.

Another line of studies has examined the effectiveness of distraction as a coping strategy for managing chronic pain. Although distraction is one of the most frequently used and recommended strategies for managing pain, results regarding its effectiveness remain variable [67]. Several factors may moderate the efficacy of distraction, e.g. motivational relevance of and engagement in the distraction task, pain intensity and habitual hypervigilance $[78,81]$. Nevertheless, under proper circumstances, distraction may be a powerful analgesic technique. For instance, the use of virtual reality distraction has proven successful in reducing experimental, procedural and chronic 
pain $[82,83]$. Virtual reality involves multisensory information facilitating full immersion in the distracting environment. Experiencing a high level of presence in the virtual environment, as well as fun in interacting with the environment, determine the efficacy of virtual reality distraction [84].

\section{Expectancy}

A plethora of studies have been performed on placebo, and to a lesser extent nocebo, effects on pain, effects that are highly dependent on expectancies of pain relief or pain increases, respectively [85]. Verbal suggestion that pain relief or increase may follow can be sufficient for inducing strong expectations, and subsequently influencing the actual experience of pain [86]. Colloca et al. [87] demonstrated that the verbal suggestion that the intensity of weak electrocutaneous shocks would increase not only led to the judgment of stimuli that were previously just above the pain threshold to be judged as much more painful, but also that tactile stimuli (i.e. stimuli previously judged as nonpainful) could be turned into painful stimuli. Neuroscientific research has indicated that the effects of expectancy on the subjective pain experience are paralleled by changes in afferent nociceptive brain areas (e.g. somatosensory areas and insula) and that this is at least partly mediated by descending pain modulatory circuits (e.g. ACC and PAG) [88-90].

Expectations may also interact with the analgesic efficacy of drugs and with other pain modulatory mechanisms. Induction of positive treatment expectancy was shown to lead to a substantial increase in the analgesic effect of a potent opioid, while induction of a negative treatment expectancy completely abolished the analgesic effect [91]. This effect on pain perception was accompanied by changes in activity in the descending pain modulatory system. Cormier et al. [92] found further evidence that expectancies might work through descending modulation and affect nociceptive processes at the spinal level. They used a conditioned pain modulation procedure, i.e. the phenomenon that a noxious stimulus (the conditioning stimulus) reduces the perceived intensity of another noxious stimulus applied on a different part of the body (the test stimulus). Conditioned pain modulation has been found to depend on descending pathways from the brainstem and to inhibit spinal nociceptive processing [93]. The effect of the conditioning stimulus on pain perception as well as the spinal nociceptive flexion reflex was moderated by expectations. Nociceptive inhibition was enhanced when participants expected the conditioning stimulus to induce analgesia; however, when participants expected more pain after the conditioning stimulus, the prototypical inhibitory effect reversed and increased pain reports and elevated reflexes were found [92].

Despite the fact that placebo and nocebo expectations may act through the same central and spinal mechanism, there may be different underlying biochemical factors [86]. Expectations of pain relief were found to act through activation of the endogenous mu-opioid system $[94,95]$, whereas expectations of pain increase may be mediated by cholecystokinin [96]. The underlying mechanism of expectation-induced analgesia may also be different from the mechanisms involved in the effects of distraction 
on pain [97], with expectation relying more on (opioid-dependent) descending pain modulation than distraction [74].

The induction of positive expectancies can also be clinically used, for instance by verbally stressing expected pain relief in patient-healthcare provider interaction. Negative expectancies about the effects of an analgesic treatment - by the patient as well as by the healthcare provider - may on the other hand reduce the efficacy of treatment [98].

Finally, expectancies may influence the recovery from acute pain and injury. Patients' expectations for recovery after traffic-related whiplash injuries have proven to be an important prognostic factor for neck pain intensity and limitations 1 year later [99]. In postoperative pain studies, expected pain and expected recovery were shown to predict actual surgical outcomes. Expectations of high acute postoperative pain were predictive of pain scores during the first postoperative days [100, 101]. Negative expectations about continuing pain, disability and ability to work led to continued pain and disability after lumbar disc surgery for back pain $[102,103]$. Also for other operations, such as total knee arthroplasty, negative expectancies were found to be associated with CPSP [104].

\section{Appraisal}

More complex cognitive processes, i.e. our interpretation of the meaning of pain, its causes and consequences, also color the experience of pain. Most research has been devoted to one specific (negative) cognitive pain appraisal, catastrophizing. Catastrophizing is defined as an exaggerated negative mental set regarding actual or anticipated pain and encompasses several aspects of negative thinking: exaggeration of the threat value of pain, rumination about pain and feeling helpless in the face of pain [105]. Catastrophizing about pain has close interconnections to some of the concepts discussed above, most notably anxiety, attention and expectancy. According to the fear-avoidance model of pain discussed earlier, catastrophizing is the precursor of pain-related fear and of increased attention towards pain (i.e. pain vigilance) [15]. It also has aspects of expectancy, i.e. expectation that the pain may not go away or becomes worse. Not surprisingly, many of the same associations between catastrophizing and pain have been reported as were found for the constructs discussed above. In healthy individuals, for example, pain catastrophizing is related to increased sensitivity to experimental pain $[105,106]$, and in chronic patients to higher reported pain intensity, more pain interference and more disability [107]. Also, the pain-modulating influences of catastrophizing seem to be associated with similar brain regions that are implied in attentional and emotional control of pain $[108,109]$, and with lower activation of descending pain-inhibitory controls [110, 111].

Pain catastrophizing has also been implicated as an important factor in the transition from acute to chronic pain. Catastrophizing predicts the persistence of pain after an acute back pain episode [112] and persistent pain after surgical intervention [27, $113,114]$. A catastrophic thinking style can interact with genetic factors in determining persistent pain. The combination of a specific gene diplotype and high levels of 
pain catastrophizing were found to increase shoulder pain intensity after exerciseinduced muscle injury and shoulder surgery more than either factor on its own [115, 116]. Many more studies in fact found associations between pain catastrophizing and pain outcomes in both healthy volunteers and pain patients; there are several reviews available that summarize this evidence [105, 106, 117].

Another higher-order cognition that has been found to influence pain perception is optimism. Optimism, as well as its reverse pessimism, is related to catastrophizing yet distinct in that it concerns a broader thinking style affecting multiple life domains. It is usually thought of as a trait characteristic, remaining relatively stable across the life span [118]. An optimistic thinking style has been related to less pain sensitivity and to less interference of pain on activities and mood [119]. In laboratory experiments, trait optimism, as well as (temporary) induced optimism, was found to lead to lower perceived pain, and this effect seemed to be mediated by lower levels of pain catastrophizing $[120,121]$. Optimism was also indicated as a protective mechanism for the development of chronic postoperative pain after surgery [122].

\section{Concluding Remarks}

The above review makes clear that multiple emotional and cognitive factors can impact on the experience of pain. Although the various factors were presented and discussed separately for the sake of this overview, it should be noted that there are profound interconnections between these factors. For instance, both pain catastrophizing and pain-related fear may lead to attention to pain; a general optimistic attitude may result in less fear and less pain catastrophizing, etc. In addition, the underlying pathways may partly overlap. Brain areas processing affective and cognitive information are heavily interconnected and in turn both have connections to sensory areas. Descending pathways play a role in many of the effects presented above. Probably the primary distinction that can be made is between emotion modulation in general (i.e. independent of the specific emotion involved) and attentional modulation because there are indications that for these two modulatory influences the underlying mechanisms may differ. The more complex cognitive factors such as pain catastrophizing and optimism probably rely on multiple underlying emotional (e.g. fear) and more basic cognitive factors (e.g. attention). For treatment and management of (chronic) pain, all of these factors might, however, constitute targets for prevention and intervention, or may be used for determination of risk for a negative pain trajectory. Discussion of treatment strategies for decreasing negative emotions and increasing positive emotions, and/or changing pain cognitions, is beyond the focus of this chapter but can be found elsewhere [123-126]. The principal message is that proper understanding of the experience of pain always involves awareness of emotional and cognitive aspects involved. Pain is a complex experience shaped by multiple factors that are unique for each individual. 


\section{References}

1 Merskey H, Bogduk N: IASP Task Force on Taxonomy, Classification of Chronic Pain; Part III: Pain Terms, a Current List with Definitions and Notes on Usage. Seattle, IASP Press, 1994.

2 Hirsh AT, George SZ, Bialosky JE, Robinson ME: Fear of pain, pain catastrophizing, and acute pain perception: relative prediction and timing of assessment. J Pain 2008;9:806-912.

3 Horn ME, Alappattu MJ, Gay CW, Bishop M: Fear of severe pain mediates sex differences in pain sensitivity responses to thermal stimuli. Pain Res Treatment 2014;2014:897953.

4 George SZ, Dannecker EA, Robinson ME: Fear of pain, not pain catastrophizing, predicts acute pain intensity, but neither factor predicts tolerance or blood pressure reactivity: an experimental investigation in pain-free individuals. Eur J Pain 2006; 10: 457-465.

5 Roelofs J, Peters ML, Deutz J, Spijker C, Vlaeyen JWS: The Fear of Pain Questionnaire (FPQ): further psychometric examination in a non-clinical sample. Pain 2005;116:339-346.

6 Robinson ME, Bialosky JE, Bishop MD, Price DD, George SZ: Supra-threshold scaling, temporal summation, and after-sensation: relationships to each other and anxiety/fear. J Pain Res 2010;3:25-32.

7 van Wijk AJ, Hoogstraten J: Anxiety and pain during dental injections. J Dent 2009;37:700-704.

8 Rhudy JL, Meagher MW: Fear and anxiety: divergent effects on human pain thresholds. Pain 2000;84:6575.

9 Wiech K, Tracey I: The influence of negative emotions on pain: behavioral effects and neural mechanisms. Neuroimage 2009;47:987-994.

10 Jennings EM, Okine BN, Roche M, Finn DP: Stressinduced hyperalgesia. Prog Neurobiol 2014;121:1-18.

11 Bushnell MC, Čeko M, Low LA: Cognitive and emotional control of pain and its disruption in chronic pain. Nat Rev Neurosci 2103;14:502-511.

12 Ploghaus A, Narain C, Beckmann CF, Clare S, Bantick S, Wise R, Matthews PM, Rawlins NP, Tracey I: Exacerbation of pain by anxiety is associated with activity in a hippocampal network. J Neurosci 2001;21: 9896-9903.

13 Ploner M, Lee MC, Wiech K, Bingel U, Tracey I: Prestimulus functional connectivity determines pain perception in humans. Proc Natl Acad Sci U S A 2010;107:355-360.

14 Roy M, Piche M, Chen J, f, Peretz I, Rainville P: Cerebral and spinal modulation of pain by emotions. Proc Natl Acad Sci U S A 2009;106:20900-20905.

15 Leeuw M, Goossens ME, Linton SJ, Crombez G, Boersma K, Vlaeyen JW: The fear-avoidance model of musculoskeletal pain: current state of scientific evidence. J Behav Med 2007;30:77-94.
16 Vlaeyen JWS, Linton SJ: Fear-avoidance model of chronic musculoskeletal pain: 12 years on. Pain 2012;153:1144-1147.

17 Peters ML, Vlaeyen JWS, Weber WE: The joint contribution of physical pathology, pain-related fear and catastrophizing to chronic pain disability. Pain 2005; 113:45-50.

18 Zale EL, Lange KL, Fields SA, Ditre JW: The relation between pain-related fear and disability: a metaanalysis. J Pain 2013;14:1019-1030.

19 Boersma K, Linton SJ: Screening to identify patients at risk: profiles of psychological risk factors for early intervention. Clin J Pain 2005;21:38-43.

20 Linton SJ: A review of psychological risk factors in back and neck pain. Spine 2000;25:1148-1156.

21 Melloh M, Elfering A, Egli Presland C, Roeder C, Barz T, Rolli Salathé C, Tamcan O, Mueller U, Theis JC: Identification of prognostic factors for chronicity in patients with low back pain: a review of screening instruments. Int Orthop 2009;33:301-313.

22 Linton SJ, Buer N, Vlaeyen JWS, Hellsing AL: Are fear-avoidance beliefs related to the inception of an episode of back pain? A prospective study. Psychol Health 1999;14:1051-1059.

23 Picavet HS, Vlaeyen JWS, Schouten JS: Pain catastrophizing and kinesiophobia: predictors of chronic low back pain. Am J Epidemiol 2002;156:1028-1034.

24 Kehlet H, Jensen TS, Woolf CJ: Persistent postsurgical pain: risk factors and prevention. Lancet 2006; 367:1618-1625.

25 Macrae WA: Chronic post-surgical pain: 10 years on Br J Anaesth 2008;101:77-86.

26 Peters ML, Sommer M, de Rijke JM, Kessels F, Heineman E, Patijn J, Marcus MA, Vlaeyen JW, van Keef M: Somatic and psychologic predictors of longterm unfavorable outcome after surgical intervention. Ann Surg 2007;245:487-494.

27 Theunissen M, Peters ML, Bruce J, Gramke HF, Marcus MA: Preoperative anxiety and catastrophizing: a systematic review and meta-analysis of the association with chronic postsurgical pain. Clin J Pain 2012;28:819-841.

28 Zelman DC, Howland EW, Nichols SN, Cleeland CS: The effects of induced mood on laboratory pain. Pain 1991;46:105-111.

29 Berna C, Leknes S, Holmes EA, Edwards RA, Goodwin GM, Tracey I: Induction of depressed mood disrupts emotion regulation neurocircuitry and enhances pain unpleasantness. Biol Psychiatry 2010;67: $1083-1090$

30 Bär KJ, Wagner G, Koschke M, Boettger S, Boettger MK, Schlosser R, Sauer H: Increased prefrontal activation during pain perception in major depression. Biol Psychiatry 2007;62:1281-1287. 
31 Strigo IA, Simmons AN, Matthews SC, Craig A Paulus MP: Association of major depressive disorder with altered functional brain response during anticipation and processing of heat pain. Arch Gen Psychiatry 2008;65:1275-1284.

32 Bair MJ, Robinson RL, Katon W, Kroenke K: Depression and pain comorbidity. Arch Int Med 2003; 163:2433-2445.

33 Dersh J, Gatchel RJ, Mayer T, Polatin P, Temple OR: Prevalence of psychiatric disorders in patients with chronic disabling occupational spinal disorders. Spine 2006;31:1156-1162.

34 Gaskin, ME, Greene AF, Robinson ME, Geisser ME: Negative affect and the experience of chronic pain. J Psychosom Res 1992;36:707-713.

35 Mangelli L, Gribbin N, Buchi S, Allard S, Sensky T: Psychological well-being in rheumatoid arthritis: relationship to 'disease' variables and affective disturbance. Psychother Psychosom 2002;71:112-116.

36 Giesecke T, Gracely RH, Williams DA, Geisser ME, Petzke FW, Clauw DJ: The relationship between depression, clinical pain, and experimental pain in a chronic pain cohort. Arthritis Rheum 2005;52:15771584.

37 Schweinhardt P, Kalk N, Wartolowska K, Chessell I, Wordsworth P, Tracey I: Investigation into the neural correlates of emotional augmentation of clinical pain. Neuroimage 2008;40:759-766.

38 Linton SJ: A transdiagnostic approach to pain and emotion. J Appl Biobehav Res 2013;18:82-103.

39 Walker AK, Kavelaars A, Heijnen CJ, Dantzer R: Neuroinflammation and comorbidity of pain and depression. Pharmacol Rev 2014;66:80-101.

40 Gracely RH, Ceko M, Bushnell MC: Fibromyalgia and depression. Pain Res Treat 2012;2012:486590.

41 Jarvik JG, Hollingworth W, Heagerty PJ, Haynor DR, Boyco EJ, Deyo RA: Three-year incidence of low back pain in an initially asymptomatic cohort. Clinical and imaging risk factors. Spine 2005;30:15411548.

42 Larson SL, Clark MR, Eaton WW: Depressive disorder as a long-term antecedent risk factor for incident back pain: a 13-year follow-up study from the Baltimore Epidemiological Catchment Area sample. Psychol Med 2004;34:211-219.

43 Hinrichs-Rocker A, Schulz K, Jarvinen I, Lefering R, Simanski C, Neugebauer EA: Psychosocial predictors and correlates for chronic post-surgical pain (CPSP) - a systematic review. Eur J Pain 2009;13: 719-730.

44 Celestin J, Edwards RR, Jamison RN: Pretreatment psychosocial variables as predictors of outcomes following lumbar surgery and spinal cord stimulation: a systematic review and literature synthesis. Pain Med 2009;10:639-653.
45 Bruehl S, Burns JW, Chung OY, Ward P, Johnson B: Anger and pain sensitivity in chronic low back pain patients and pain-free controls: the role of endogenous opioids. Pain 2002;99:223-233.

46 Middendorp H, Lumley MA, Jacobs JWG, Bijlsma JWJ, Geenen R: The effects of anger and sadness on clinical pain reports and experimentally-induced pain thresholds in women with and without fibromyalgia. Arthritis Care Res (Hoboken) 2010;62: 1370-1376.

47 Bruehl S, Chung OY, Donahue BS, Burns JW: Anger regulation style, postoperative pain, and relationship to the A118G mu opioid receptor gene polymorphism: a preliminary study. J Behav Med 2006;29: 161-169.

48 Bruehl S, Burns JW, Chung OY, Chont M: Pain-related effects of trait anger expression: neural substrates and the role of endogenous opioid mechanisms. Neurosci Biobehav Rev 2009;33:475-491.

49 Burns JW, Gerhart JI, Bruehl S, Peterson KM, Smith DA, Porter LS, Schuster E, Kinner E, Buvanendran A, Fras AM, Keefe FJ: Anger arousal and behavioral anger regulation in everyday life among patients with chronic low back pain: relationships to patient pain and function. Health Psychol 2015;34:547-555.

50 Bruehl S, Liu X, Burns JW, Chont M, Jamison RN: Associations between daily chronic pain intensity, daily anger expression, and trait anger expressiveness: an ecological momentary assessment study. Pain 2012;153:2352-2358.

51 Greenwood KA, Thurston R, Rumble M, Waters SJ, Keefe FJ: Anger and persistent pain: current status and future directions. Pain 2003;103:1-5.

52 Trost Z, Vangronsveld K, Linton SJ, Quartana PJ, Sullivan MJ: Cognitive dimensions of anger in chronic pain. Psychosom Med 2011;73:612-619.

53 Watson D, Tellegen A: Toward a consensual structure of mood. Psychol Bull 1985;98:219-235.

54 Finan PH, Garland EL: The role of positive affect in pain and its treatment. Clin J Pain 2015;31:177-187.

55 Williams AE, Rhudy JL: Affective modulation of eyeblink reactions to noxious sural nerve stimulation: a supraspinal measure of nociceptive reactivity? Int J Psychophysiol 2007;66:255-265.

56 Rhudy JL, Williams AE, McCabe KM, Nguyen MA, Rambo P: Affective modulation of nociception at spinal and supraspinal levels. Psychophysiology 2005;42:579-587.

57 Meulders A, Meulders M, Vlaeyen JWS: Positive affect protects against deficient safety learning during extinction of fear of movement-related pain in healthy individuals scoring relatively high on trait anxiety. J Pain 2014;15:632-644.

58 Geschwind N, Meulders M, Peters ML, Vlaeyen JWS, Meulders A: Can experimentally induced positive affect attenuate generalization of fear of movement related pain? J Pain 2015;16:258-269. 
59 Pressman SD, Cohen S: Does positive affect influence health? Psychol Bull 2005;131:925-971.

60 Connelly M, Keefe FJ, Affleck G, Lunley MA, Anderson T, Waters S: Effects of day-to-day affect regulation on the pain experience of patients with rheumatoid arthritis. Pain 2007;131:162-170.

61 Fredman L, Hawkes WG, Black S, Bertrand RM, Magaziner J: Elderly patients with hip fracture with positive affect have better functional recovery over 2 years. J Am Geriatr Soc 2006;54:1074-1081.

62 Zautra AJ, Johnson LM, Davis MC: Positive affect as a source of resilience for women in chronic pain. J Consult Clin Psychol 2005;73:212-220.

63 Hausmann LRM, Parks A, Youk AO, Kwohk CK Reduction of bodily pain in response to an online positive activities intervention. J Pain 2014;15:560567.

64 Herrero R, Garcia-Palacios A, Castilla D, Molinari G, Botella C: Virtual reality for the induction of positive emotions in the treatment of fibromyalgia: a pilot study over acceptability, satisfaction, and the effect of virtual reality on mood. Cyberpsychol Behav Soc Netw 2014;17:379-384.

65 Moriarty O, McGuire BE, Finn DP: The effect of pain on cognitive function: a review of clinical and preclinical research. Prog Neurobiol 2011;93:385-404.

66 Legrain V, Van Damme S, Eccleston C, Davis KD, Seminowicz DA, Crombez G: A neurocognitive model of attention to pain: behavioral and neuroimaging evidence. Pain 2009;144:230-232.

67 Johnson $\mathrm{MH}$ : How does distraction work in the management of pain? Curr Pain Headache Rep 2005; 9:90-95.

68 Legrain V, Mancini F, Sambo CF, Torta DM, Ronga I, Valentini E: Cognitive aspects of nociception and pain: bridging neurophysiology with cognitive psychology. Neurophysiol Clin 2012;42:325-336.

69 Van Damme S, Legrain V, Vogt J, Crombez G: Keeping pain in mind: a motivational perspective on attentional processing of pain. Neurosci Biobehav Rev 2010;34:204-213.

70 Tracey I, Ploghaus A, Gati JS, Clare S, Smith S, Menon RS, Matthews PM: Imaging attentional modulation of pain in the periaqueductal gray in humans. J Neurosci 2002;22:2748-2752.

71 Valet M, Sprenger T, Boecker H, Willoch F, Rummeny E, Conrad B, Erhard T, Tolle TR: distraction modulates connectivity of the cingulo-frontal cortex and the midbrain during pain - an fMRI analysis. Pain 2004;109:399-408.

72 Villemure C, Schweinhardt P: Supraspinal pain processing: distinct roles of emotion and attention. Neuroscientist 2010;16:276-284.

73 Ford GK, Moriarty O, McGuire BE, Finn DP: Investigating the effects of distracting stimuli on nociceptive behaviour and associated alterations in brain monoamines in rats. Eur J Pain 2008;12:970-979.
74 Ford GK, Moriarty O, Okine BN, Tully E, Mulcahy A, Harhen B, Finn DP: Involvement of the endocannabinoid system in attentional modulation of nociceptive behaviour in rats. Eur J Pain 2014, DOI: 10.1002/ejp.646.

75 Villemure C, Bushnell MC: Mood influences supraspinal pain processing separately from attention. J Neurosci 2009;29:705-715.

76 Ploner M, Lee MC, Wiech K, Bingel U: Tracey I: Flexible cerebral connectivity patterns subserve contextual modulations of pain. Cereb Cortex 2011;21: 719-726.

77 Crombez G, Van Damme S, Eccleston C: Hypervigilance to pain: an experimental and clinical analysis. Pain 2005;116:4-7.

78 Van Damme S, Legrain V, Vogt J, Crombez G: Keeping pain in mind: a motivational account of attention to pain. Neurosci Biobehav Rev 2010;34:204-213.

79 Crombez G, Eccleston C, Van den Broeck A, Goubert L, Van Houdenhove B: Hypervigilance to pain in fibromyalgia: the mediating role of pain intensity and catastrophic thinking about pain. Clin J Pain 2004;20:98-102.

80 Peters ML, Crombez G: Assessment of attention to pain using handheld computer diaries. Pain Med 2007;8:S110-S120.

81 Van Ryckeghem DM, Crombez G, Van Hulle L, Van Damme S: Attentional bias towards pain-related information diminishes the efficacy of distraction. Pain 2012;153:2345-2351.

82 Botella C, García Palacios A, Baños R, Quero S, Breton-Lopez J: Virtual reality in the treatment of pain. J Cyberther Rehab 2008;1:93-100.

83 Malloy KM, Milling LS: The effectiveness of virtual reality distraction for pain reduction: a systematic review. Clin Psychol Rev 2010;30:1011-1018.

84 Triberti S, Repetto C, Riva G: Psychological factors influencing the effectiveness of virtual reality-based analgesia: a systematic review. Cyberpsychol Behav Soc Networking 2014; 17:6.

85 Benedetti F: Mechanisms of placebo and placeborelated effects across diseases and treatments. Annu Rev Pharmacol Toxicol 2008;48:33-60.

86 Benedetti F, Lanotte M, Lopiano L, Colloca L: When words are painful: unraveling the mechanisms of the nocebo effect. Neuroscience 2007;147:260-271.

87 Colloca L, Sigaudo M, Benedetti F: The role of learning in nocebo and placebo effects. Pain 2008; 136 : 211-218.

88 Keltner JR, Furst A, Fan C, Redfern R, Inglis B, Fields HL: Isolating the modulatory effect of expectation on pain transmission: a functional magnetic resonance imaging study. J Neurosci 2006;26:4437-4443.

89 Koyama T, McHaffie JG, Laurienti PJ, Coghill RC: The subjective experience of pain: where expectations become reality. Proc Natl Acad Sci U S A 2005; 102:12950-12955. 
90 Wager TD, Rilling JK, Smith EE, Sokolik A, Casey KL, Davidson RJ, Kosslyn SM, Rose RM, Cohen JD: Placebo-induced changes in FMRI in the anticipation and experience of pain. Science 2004;303: 1162-1167.

91 BingelU,WanigasekeraV,WiechK, Mhuircheartaigh RN, Lee MC, Ploner M, Tracey I: The effect of treatment expectation on drug efficacy: imaging the analgesic benefit of the opioid remifentanil. Sci Translat Med 2011;3:70ra14.

92 Cormier S, Piche M, Rainville P: Expectations modulate heterotopic noxious counter-timulation analgesia. J Pain 2013;14:114-125.

93 Bouhassira D, Danziger N: Investigation of brainstem descending pain modulation in animals and humans. Suppl Clin Neurophysiol 2006;58:134149.

94 Amanzio M, Benedetti F: Neuropharmacological dissection of placebo analgesia: expectation-activated opioid systems versus conditioning-activated specific sub-systems. J Neurosci 1999;19:484-494.

95 Zubieta JK, Bueller JA, Jackson LR, Scott DJ, Xu Y, Koeppe RA, Nichols TE, Stohler C: Placebo effects mediated by endogenous opioid activity on opioid receptors. J Neurosci 2005;25:7754-7762.

96 Benedetti F, Amanzio M, Vighetti S, Asteggiano G: The biochemical and neuroendocrine bases of the hyperalgesic nocebo effect. J Neurosci 2006;26: 12014-12022.

97 Buhle JT, Stevens BL, Friedman JJ, Wager TD: Distraction and placebo: two separate routes to pain control. Psychol Sci 2012;23:246-253.

98 Klinger R, Colloca L, Bingel U, Flor H: Placebo analgesia: clinical applications. Pain 2014;155:10551058.

99 Caroll LJ, Holm LW, Ferrari R, Ozegovic D, Cassidy DJ: Recovery in whiplash-associated disorders: do you get what you expect? J Rheumatol 2009;36:1063-1070.

100 Gramke HF, de Rijke JM, van Kleef M, Kessels AG, Peters ML, Sommer M, Marcus MA: Predictive factors of postoperative pain after day-case surgery. Clin J Pain 2009;25:455-460.

101 Sommer M, de Rijke MM, Van Kleef M, Kessels F, Peters ML, Geurts JW, Patijn J, Gramke H, Marcus MA: Predictors of acute postoperative pain after elective surgery. Clin J Pain 2010;26:87-94.

102 den Boer JJ, Oostendorp RA, Beems T, Munneke $\mathrm{M}$, Evers AW: Continued disability and pain after lumbar disc surgery: the role of cognitive-behavioral factors. Pain 2006;123:45-52.

103 Johansson A, Lintom SJ, Rosenblad A, Bergkvist L, Nilssom O: A prospective study of cognitive behavioural factors as predictors of pain, disability and quality of life one year after lumbar disc surgery. Disabil Rehabil 2010;32:521-529.
104 Sullivan S, Tanzer M, Reardon G, Amirault D, Dunbar M, Stanish W: The role of presurgical expectancies in predicting pain and function one year following total knee arthroplasty. Pain 2011;152: 2287-2293.

105 Sullivan MJ, Thorn B, Haythornthwaite J, Keefe F, Martin M, Bradley LA, Lefebvre JC: Theoretical perspectives on the relation between catastrophizing and pain. Clin J Pain 2001;17:52-64.

106 Quartana PJ, Campbell CM, Edwards RR: Pain catastrophizing: a critical review. Expert Rev Neurother 2009;9:745-758.

107 Lamé IE, Peters ML, Vlaeyen JWS, van Kleef M, Patijn J: Quality of life in chronic pain is more associated with beliefs about pain, than with pain intensity. Eur J Pain 2005;9:15-24.

108 Gracely RH, Geisser ME, Giesecke T, Grant MA, Petzke F, Williams DA, Clauw DJ: Pain catastrophizing and neural responses to pain among persons with fibromyalgia. Brain 2004;127:835-843.

109 Seminowicz DA, Davis KD: Cortical responses to pain in healthy individuals depends on pain catastrophizing. Pain 2006;120:297-306.

110 Goodin BR, McGuire L, Allshouse M, Stapleton L, Haythornthwaite JA, Burns N, Mayes LA, Edwards RE: Associations between catastrophizing and endogenous pain-inhibitory processes: sex differences. J Pain 2009;10:180-190.

111 Rhudy JL, Maynard LJ, Russell JL: Does in vivo catastrophizing engage descending modulation of spinal nociception? J Pain 2007;8:325-333.

112 Severeijns R, Vlaeyen JW, van den Hout MA, Picavet HS: Pain catastrophizing and consequences of musculoskeletal pain: a prospective study in the Dutch community. J Pain 2005;6:125-132.

113 Edwards RR, Haythornthwaite JA, Smith MT, Klick B, Katz JN: Catastrophizing and depressive symptoms as prospective predictors of outcomes following total knee replacement. Pain Res Manag 2009;14:307-311.

114 Riddle DL, Wade JB, Jiranek WA, Kong X: Preoperative pain catastrophizing predicts pain outcome after knee arthroplasty. Clin Orthop Relat Res 2010;468:798-806.

115 George SZ, Dover GC, Wallace MR, Sack BK, Herbstman DM, Aydog EM, Fillingim RB: Biopsychosocial influence on exercise-induced delayed onset muscle soreness at the shoulder: pain catastrophizing and catechol-O-methyltransferase (COMT) diplotype predict pain ratings. Clin J Pain 2008;24:793-801.

116 George SZ, Wallace MR, Wright TW, Moser MW, Greenfield WH, Sack BH, Herbstman DM, Fillingim RB: Evidence for a biopsychosocial influence on shoulder pain: Pain catastrophizing and catechol-O-methyltransferase (COMT) diplotype predict clinical pain ratings. Pain 2008;136:53-61. 
117 Turner JA, Aaron LA: Pain-related catastrophizing: what is it? Clin J Pain 2001;17:65-71.

118 Carver CS, Scheier MF, Segerstrom SC: Optimism. Clin Psychol Rev 2010;30:879-889.

119 Goodin BR, Bulls HW: Optimism and the experience of pain: benefits of seeing the glass as half full. Curr Pain Headache Rep 2013;17:329-337.

120 Hanssen MM, Peters ML, Vlaeyen JW, Meevissen Y, Vancleef LM: Optimism lowers pain: evidence of the causal status and underlying mechanisms. Pain 2013;154:53-58.

121 Hanssen MM, Vancleef LMG, Vlaeyen JW, Peters ML: More optimism, less pain! The influence of generalized and pain-specific expectations on experienced cold-pressor pain. J Behav Med 2014;37: 47-58.

122 Powell R, Johnston M, Smith WC, King PM, Chambers WA, Krukowski Z, McKee L, Bruce J: Psychological risk factors for chronic post-surgical pain after inguinal hernia repair surgery: a prospective cohort study. Eur J Pain 2012;16:600-610.
123 De Peuter S, de Jong J, Crombez G, Vlaeyen JW: The nature and treatment of pain-related fear in chronic musculoskeletal pain. J Cogn Psychother 2009;23:85-103.

124 Eccleston C, Morley SJ, Williams AD: Psychological approaches to chronic pain management: evidence and challenges. Br J Anaesth 2013;111:5963.

125 Ehde DM, Dillworth TM, Turner JA: Cognitivebehavioral therapy for individuals With chronic pain efficacy, innovations, and directions for research. Am Psychol 2014;69:153-166.

126 Nicholas MK, Linton SJ, Watson PJ, Main CJ: Early identification and management of psychological risk factors ('yellow flags') in patients with low back pain: a reappraisal. Phys Ther 2011;91:737-753.

Prof. Madelon L. Peters

Department of Clinical Psychological Science, Maastricht University

Universiteitsingel 40

NL-6200 MD Maastricht (The Netherlands)

E-Mail madelon.peters@maastrichtuniversity.nl 